\title{
Kepastian Hukum dalam Pasal 112 dan Pasal 127 Undang- Undang Nomor 35 Tahun 2009 tentang Narkotika
}

\author{
Fitri Resnawardhani \\ University of Jember, Indonesia \\ dewi.congir@gmail.com
}

\begin{abstract}
Narcotics are commonly used for the world of health. Along with the times, the use and development of narcotics are increasing, no longer for health services. In Law Number 35 of 2009, concerning narcotics, there are many articles that discuss multi-interpretations. Among them include Article 112 and Article 127. This article tries to understand whether Article 112 and Article 127 have provided legal certainty against the Protecting and Fighting of Narcotics Borders, as well as discusses the policy formulation of ius constituendum on the protection and overcoming of narcotic acts. The type of research used is normative juridical, namely legal research, that establishes laws as a building system of norms. Article 112 and Article 127 of the Narcotics Law have not provided legal certainty, because the article editorial still contains multiple interpretations and meanings. Article 112 stipulates not to sell and circulate the editorial. This article ends with a suggestion to add to the article provided in Article 112.
\end{abstract}

KEYWORDS: Narcotics, Narcotics Abusers, Actors of Narcotics Crime.

cc) () () Copyright $\odot 2019$ by Author(s)

This work is licensed under a Creative Commons Attribution-ShareAlike 4.0

International License. All writings published in this journal are personal views of the authors and do not represent the views of this journal and the author's affiliated institutions.

\section{HOW TO CITE:}

Resnawardhani, Fitri. "Kepastian Hukum dalam Pasal 112 dan Pasal 127 Undang-Undang Nomor 35 Tahun 2009 tentang Narkotika" (2019) 6:1 Lentera Hukum 117-132.

Submitted: November 07, 2018 Revised: March 18, 2019 Accepted: April 02, 2019 


\section{PENDAHULUAN}

Narkotika sejatinya hanya diperuntukan sebagai pengobatan, jenis narkotika pertama yang digunakan ialah opium. ${ }^{1}$ Pada bidang pengobatan dan kesehatan, narkotika cukup diperlukan ketersediaannya, akan tetapi apabila disalahgunakan akan menimbulkan dampak yang berbahaya, sehingga harus dilakukan pengawasan dan pengendalian yang ketat. $^{2}$ Saat ini, perkembangan narkotika semakin pesat dan tidak lagi untuk kepentingan pelayanan kesehatan tetapi untuk memperoleh keuntungan secara besar dengan cara perdagangan narkotika secara ilegal ke berbagai negara. ${ }^{3}$ Perkembangan narkotika yang pesat telah membuat warga dunia resah karena akibat negatif yang ditimbulkan dari penyalahgunaan narkotika bagi kehidupan. Penyalahgunaan narkotika tersebut telah menyebar keseluruh negara termasuk Indonesia.

Penyalahgunaan obat-obat terlarang di Indonesia seperti narkotika, psikotropika dan zat adiktif lainnya telah berkembang dan menjadikan Indonesia sebagai negara darurat narkoba. Penyalahgunaan narkotika di Indonesia telah sampai pada titik yang sangat memprihatinkan dan membahayakan dengan sasaran yang telah menyentuh seluruh lapisan masyarakat. Hal tersebut dapat dilihat dari survei yang telah dilakukan oleh Badan Narkotika Nasional Republik Indonesia sepanjang tahun 2017. Berdasarkan survei tersebut, terdapat 3.376 .115 orang pada kelompok usia 10-59 tahun, jumlah tersebut merupakan julah penyalahguna narkoba sepanjang tahun $2017^{4}$

Pengaturan mengenai Narkotika sendiri dalam sejarah hanya terdapat dalam Verdovende Middelen Ordonnantie (Staatsblad No. 278 jo No. 536). ${ }^{5}$ Aturan ini dianggap tidak dapat mengikuti perkembangan lalu lintas dan alat-alat transportasi yang mendorong terjadinya kegiatan penyebaran dan pemasokan narkotika ke Indonesia. Oleh karena itu berdasarkan Resolusi The United Nations Economic and Social Council, Nomor 1474 (XLVIII) tanggal 24 Maret 1970 konferensi PBB tentang Adopsi Protokol Psikotropika dilaksanakan sehingga menghasilkan Convention on Psychotropic Substances $1971 .^{6}$ Berdasarkan hasil konvensi tersebut, pemerintah Indonesia mengsahkan Convention on Psychotropic Substances 1971 dalam Undang-Undang Republik Indonesia Nomor 8 Tahun 1996 dengan reservation. ${ }^{7}$ Seiring perkembangannya, peraturan mengenai narkotika telah mengalami beberapa perubahan. Peraturan mengenai narkotika saat ini ialah UndangUndang Republik Indonesia Nomor 35 Tahun 2009 tentang Narkotika.

Pasal 1 angka 1 Undang-Undang Nomor 35 Tahun 2009 tentang Narkotika (selanjutnya disebut UU Narkotika) menyatakan bahwa Narkotika adalah zat atau

1 Kusno Adi, Diversi Sebagai Upaya Alternatif Penanggulangan Tindak Pidana Narkotika Oleh Anak, lst ed (Malang: UMM Press, 2009). Hlm.3

Ibid.

Ibid.

4 Pusat Penelitian Data dan Informasi Badan Narkotika Nasional Republik Indonesia, Survei Nasional Penyalahgunaan Narkoba di 34 Provinsi Tahun 2017, Laporan Tahunan (Jakarta: Badan Narkotika Nasional Republik Indonesia, 2017). Hlm.28

5 Siswanto Sunarso, Politik Hukum dalam Undang-Undang Narkotika (UU Nomor 35 Tahun 2009) (Jakarta: Rineka Cipta, 2012). Hlm.1l

Ibid.

7 Ibid. 
obat yang berasal dari tanaman atau bukan tanaman, baik sintetis maupun semisintetis, yang dapat menyebabkan penurunan atau perubahan kesadaran, hilangnya rasa, mengurangi sampai menghilangkan rasa nyeri, dan dapat menimbulkan ketergantungan, yang dibedakan ke dalam beberapa golongan seperti yang terdapat dalam lampiran UU Narkotika. Pada konsideran UU Narkotika menyatakan bahwa narkotika di satu sisi ialah obat atau bahan yang bermanfaat dan pengembangan ilmu pengetahuan dan di sisi lain dapat pula menimbulkan ketergantungan yang sangat merugikan jika disalahgunakan tanpa pengendalian dan pengawasan yang ketat.

Pada kasus-kasus narkotika, terdapat beberapa pasal yang sering digunakan untuk menjerat pelaku, ialah Pasal 112, Pasal 114, dan Pasal 127 UU Narkotika. Ketiga pasal tersebut, terdapat dua pasal yang multitafsir dan ketidakjelasan rumusan yaitu Pasal 112 dan Pasal 127 UU Narkotika. Pasal multitafsir tersebut akan mengakibatkan para pelaku kejahatan narkotika (pengedar) akan berlindung seolah-olah dia korban kejahatan narkotika. Hal tersebut akan berdampak pada penjatuhan hukuman dengan hukuman yang singkat sehingga menimbulkan ketidakadilan pada proses pelaksanaannya.

Seperti contoh kasus pada Putusan Nomor: 161/Pid.Sus/2016/PN.Plg. Pada kasus ini terdakwa didakwa sebagai pelaku atau pengedar narkotika, akan tetapi Majelis Hakim dalam putusannya menyatakan bahwa terdakwa adalah pemakai narkotika. Kasus tersebut dengan terdakwa bernama Dedy Sanjaya dan M kiki Prataman. Kedua terdakwa oleh Penuntut Umum didakwa dengan dakwaan pertama Pasal 114 Ayat (1) jo Pasal 132 Ayat (1) UU Narkotika dan/atau dakwaan kedua yaitu Pasal 112 Ayat (1) UU Narkotika, dan/atau dakwaan ketiga yaitu Pasal 127 Ayat (1) Huruf a UU Narkotika jo Pasal 55 Ayat (1) ke-1 KUHP. Pada kasus ini terdakwa terbukti menguasai dan memiliki narkotika golongan 1 bukan tanaman sebanyak 1 paket sabu dengan berat 0,73 gram. Dari penemuan barang bukti tersebut seharusnya terdakwa dijerat Pasal 112 UU Narkotika. Pada kenyataannya Majelis Hakim menjatuhkan putusan dengan menyatakan bahwa terdakwa merupakan pemakai atau pecandu atau penyalahguna narkotik sehingga terdakwa dijatuhi sanksi pidana 2 tahun penjara. Sayangnya, penjatuhan hukuman yang menyatakan bahwa terdakwa merupakan pemakai atau pecandu atau penyalahguna narkotika tidak diikuti atau dilakukannya tes urin kepada kedua terdakwa untuk memperjelas apakah kedua terdakwa benar sebagai pecandu atau tidak. Terdakwa dalam kasus tersebut seharusnya dikenakan Pasal 112 UU Narkotika.

Adanya ketidakjelasan rumusan dan multitafsir terhadap Pasal 112 dan Pasal 127 UU Narkotika, memunculkan ketertarikan untuk mengkaji dengan dua permasalahan. Permasalahan pertama adalah apakah Pasal 112 dan Pasal 127 UU Narkotika telah memberikan kepastian hukum terhadap penyalahguna dan pelaku tindak pidana narkotika. Permasalahan kedua adalah bagaimanakah kebijakan formulasi ius constituendum terhadap penyalahgunaan dan pelaku tindak pidana narkotika.

Metode penelitian ini menggunakan tipe penelitian yuridis normatif ialah suatu penelitian yang difokuskan untuk mengkaji penerapan norma-norma dalam hukum 
positif yang berlaku. Adapun pendekatan masalah yang digunakan ialah dengan menggunakan pendekatan perundang-undangan (Statute Approach) yang dilakukan dengan menelaah semua undang-undang dan regulasi yang bersangkutan dengan isu hukum yang diangkat ${ }^{8}$, dan pendekatan konseptual (Conceptual Approach) yang dilakukan dengan meneliti doktrin-doktrin yang berkembang dalam ilmu hukum yang bersangkutan dengan isu hukum yang sedang diangkat. ${ }^{9}$

\section{KEPASTIAN HUKUM PASAL 112 DAN PASAL 127 UU NARKOTIKA TERHADAP PENYALAHGUNA DAN PELAKU TINDAK PIDANA NARKOTIKA}

Narkotika berasal dari bahasa Inggris yaitu narcotics yang artinya obat bius, yang dalam bahasa Yunani "narcosis" yang mempunyai arti menidurkan atau membiuskan. ${ }^{10}$ Secara garis besar, narkotika sering disebutkan sebagai suatu zat yang dapat menimbulkan transformasi perasaan, suasana penglihatan, hal tersebut terjadi karena zat yang terkandung dalam narkotika mempengaruhi susunan syaraf pusat. ${ }^{1 l}$ Pasal 1 angka 1 UU Narkotika menyatakan bahwa narkotika adalah zat atau obat yang berasal dari tanaman atau bukan tanaman, baik sintetis maupun semisintetis, yang dapat menyebabkan penurunan atau perubahan kesadaran, hilangnya rasa, mengurangi sampai menghilangkan rasa nyeri, dan dapat menimbulkan ketergantungan, yang dibedakan ke dalam golongan-golongan sebagaimana terlampir dalam Undang-Undang ini.

Penyalahgunaan narkotika ialah salah satu jenis kejahatan yang memiliki dampak sosial yang sangat luas serta kompleks. ${ }^{12}$ Pada konsideran huruf c UU Narkotika disebutkan bahwa narkotika di satu sisi ialah obat atau bahan yang bermanfaat dalam bidang pengobatan atau pelayanan kesehatan dan pegembangan ilmu pengetahuan dan di sisi lain dapat pula menimbulkan ketergantungan yang sangat merugikan apabila disalahgunakan atau digunakan tanpa pengendalian dan pengawasan yang ketat dan saksama. Pada Pasal 1 angka 15 UU Narkotika dijelaskan bahwa penyalah guna adalah orang yang menggunakan narkotika tanpa hak atau melawan hukum.

Undang-Undang Narkotika menyatakan secara tegas bahwa narkotika hanya dapat digunakan untuk kepentingan pelayanan kesehatan dan/atau pengembangan ilmu pengetahuan dan teknologi, hal tersebut secara jelas tertuang dalam Pasal 7. Hal tersbeut dapat diartikan bahwa apabila narkotika tersebut digunakan untuk kepentingan pribadi dan tanpa hak, maka dapat dikenakan pidana. Penggunaan narkotika golongan 1 dibatasi hanya untuk kepentingan pengembangan ilmu

\footnotetext{
Peter Mahmud Marzuki, Penelitian Hukum, revisi ed (Jakarta: Prenadamedia Group, 2015). Hlm.133

Ibid. Hlm.135-136

10 Kusno Adi, Kebijakan Kriminal Dalam Penanggulangan Tindak Pidana Narkotika Oleh Anak, pertama ed (Malang: UMM Press, 2009). Hlm.12

11 Dit Narkotika Konserse Polri, Penanggulangan Penyalahgunaan dan Peredaran Gelap Narkotika yang Dilaksanakan Oleh Polri (Jakarta: Mabes Polri, 2002). Hlm.2

12 Adi, supra note 10. Hlm.17
} 
pengetahuan dan teknologi dan untuk readgensia diagnostik, serta reagensia laboratorium setelah mendapatkan persetujuan Menteri atas rekomnedasi Kepala Badan Pengawas Obat dan Makanan. Pembatasan tersebut tertuang dalam Pasal 8 Ayat (2) UU Narkotika. Sehingga apabila seseorang melanggar ketentuan pasal tersebut maka dapat dikenakan sanksi pidana.

Penerapkan sanksi pidana terhadap pelaku tindak pidana narkotika dan penyalahguna narkotika berdasarkan pasal-pasal yang terdapat dalam UU Narkotika. Pasal yang sering digunakan dalam kasus seperti ini ialah Pasal 112 dan Pasal 127 UU Narkotika. Pasal 112 UU Narkotika terdiri dari 2 ayat yang berbunyi:

"Setiap orang yang tanpa hak atau melawan hukum memiliki, menyimpan, menguasai, atau menyediakan Narkotika Golongan I bukan tanaman, dipidana dengan pidana penjara paling singkat 4 (empat) tahun dan paling lama 12 (dua belas) tahun dan pidana denda paling sedikit Rp.800.000.00,00 (delapan ratus juta rupiah) dan paling banyak Rp.8.000.000.000,00 (delapan miliar rupiah)."

"Dalam hal perbuatan memiliki, menyimpan menguasai, atau menydeiakan Narkotika Golongan I bukan tanaman sebagaimana dimaksud pada ayat (l) beratnya melebihi 5 (lima) gram, pelaku dipidana dengan pidana penjara seumur hidup atau pidana penjara paling singkat 5 (lima) tahun dan paling lama 20 (dua puluh) tahun dan pidana denda maksimum sebagaimana dimaksud pada ayat (l) ditambah $1 / 3$ (sepertiga)"

\section{Pasal 127 UU Narkotika berbunyi:}

"Setiap penyalah guna: Narkotikan Golongan I bagi diri sendiri dipidana dengan pidana penjara paling lama 4 (empat) tahun; Narkotika Golongan II bagi diri sendiri dipidana dengan pidana penjara paling lama 2 (dua) tahun; dan Narkotika Golongan III bagi diri sendiri dipidana dengan pidana penjara paling lama l (satu) tahun.

"Dalam memutus perkara sebagaimana dimaksud pada ayat (1), hakim wajib memperhatikan ketentuan sebagaimana dimaksud dalam Pasal 54, Pasal 55, dan Pasal 103"

"Dalam hal penyalah guna sebagaimana dimaksud pada ayat (1) dapat dibuktikan atau terbukti sebagai korban penyalahgunaan Narkotika, penyalah guna tersebut wajib menjalani rehabilitasi medis dan rehabilitasi sosial."

Berdasarkan pemaparan mengenai apa yang diatur dalam Pasal 112 dan Pasal 127 UU Narkotika, terdapat hal yang menyebabkan multitafsir atau ambigu dalam penerapannya. Multitafsir dan ambiguitas tersebut terdapat dalam Pasal 112 UU Narkotika. Pasal 112 UU Narkotika banyak digunakan untuk menjerat para pelaku tindak pidana narkotika, sedangkan Pasal 127 UU Narkotika sering diterapkan pada korban penyalah guna narkotika. Apabila melihat unsur-unsur yang terdapat dalam Pasal 112 UU Narkotita yaitu setiap orang, tanpa hak atau melawan hukum, memiliki, 
menyimpan, menguasai, atau menyediakan. Maksud dari setiap orang adalah orang perseorangan. Arti dari kata memiliki menurut Kamus Besar Bahasa Indonesia terdiri dari 2 arti, yaitu mempunyia dan mengambil secara tidak sah untuk dijadikan kepunyaan. ${ }^{13}$ Menyimpan dalam Kamus Besar Bahasa Indonesia mengandung arti manaruh ditempat yang aman supaya jangan rusak, hilang, dan sebagainya, mengemasi, membereskan, membenahi. ${ }^{14}$ Jadi, unsur menyimpan dalam Pasal 112 UU Narkotika memiliki arti bahwa pelaku menaruh Narkotika tersebut ditempat yang aman. Menguasai dalam Kamus Besar Bahasa Indonesia mengandung arti berkuasa atas (sesuatu), memegang kekuasaan atas (sesuatu). ${ }^{15}$ Berarti menguasai dalam unsur Pasal 112 UU Narkotika mengandung arti bahwa narkotika tersebut berada dalam kuasa seseorang (pelaku) atau pelaku memegang kuasa atas narkotika tersebut. Unsur selanjutnya ialah menyediakan, dalam Kamus Besar Bahasa Indonesia menyediakan mengandung arti menyiapkan; mempersiapkan. ${ }^{16}$ Berarti unsur menyediakan dalam Pasal 112 UU Narkotika mengandung arti bahwa orang tersebut menyiapkan atau mempersiapkan narkotika.

Berbeda dengan Pasal 112 UU Narkotika, Pasal 127 UU Narkotika sudah secara jelas menyebutkan bahwa Pasal 127 tersebut dikhususkan untuk penyalahguna narkotika. Jika membaca dan menganalisis unsur-unsur dari Pasal 112 UU Narkotika, seharusnya penyalahguna Narkotika juga dapat dikenakan sanksi menggunakan Pasal 112. Penyalah guna narkotika dalam Pasal 1 angka 15 UU Narkotika ialah orang yang menggunakan Narkotika tanpa hak atau melawan hukum. Penyalahguna narkotika, untuk dapat menggunakan narkotika berarti narkotika tersebut harus dimiliki, disimpan, berada dalam kuasanya dan menyediakan. Tidak mungkin penyalahguna narkotika menggunakan narkotika tetapi narkotika tersebut tidak berada dalam kuasanya. Berdasarkan analisis tersebut, seharusnya Pasal 112 UU Narkotika dapat diterapkan pada penyalahguna narkotika. Pada praktiknya penggunaan pasal tersebut masih terjadi ambiguitas dan multitafsir, apakah pasal tersebut dapat diterapkan untuk penyalahguna narkotika atau tidak. Pasal yang multitafsir itulah yang sering dimanfaatkan oleh para pihak yang berkepentingan terutama para pelaku tindak pidana berlindung sebagai penyalahguna narkotika untuk menghindari sanksi pidana yang lebih berat.

Pasal 112 dan Pasal 127 UU Narkotika selain mengakibatkan multitafsir, juga menimbulkan suatu ketidakpastian hukum dalam penerapannya. Supaya tujuan dari hukum tersebut tercapai, maka dibutuhkan suatu kaedah hukum yang tegas, jelas, tidak mempunyai arti ganda, penerapannya secara konsisten, dan dipertahankan secara pasti, hal diatas disebut kepastian hukum. kepastian hukum adalah ciri yang tidak dapat dilepaskan dari hukum itu sendiri, terutama hukum yang tertulis, hukum akan

\footnotetext{
13 KEMDIKBUD, "Informasi: Temukan Bantuan Menggunakan KBBI Daring", (23 July 2018), online: https://kbbi.kemdikbud.go.id/entri/memiliki. diakses pada Tanggal 17 Oktober 2018, Pukul 11.27 WIB.

14 Ibid.

15 Ibid.

16 Ibid.
} 
kehilangan maknanya apabila tidak disertai dengan suatu kepastian hukum karena hukum tidak dapat dijadikan sebagai pedoman berprilaku lagi bagi semua orang dengan kata lain tidak ada hukum apabila tidak ada suatu kepastian hukum. ${ }^{17}$

Gustav Radbruch menyatakan bahwa orientasi dari tujuan hukum ialah kepastian hukum. beliau menyatakan bahwa kepastian hukum merupakan suatu tuntutan pertama kepada hukum yang tuntutan tersebut berupa hukum yang berlaku secara pasti. Beliau jeuga menambahkan bahwa hukum itu harus diataati supaya hukum tersebut sungguh-sungguh positif. ${ }^{18}$

Kepastian hukum tersebut tidak terwujud dengan sendirinya saat diundangkan dan diberlakukan. Hukum harus masih diterapkan oleh penegak hukum (pelaksana hukum praktis). Supaya kepastian hukum tersebut benar-benar dapat diterapkan maka diperlukan suatu kepastian hukum pada penerapannya. Hukum positif memberikan jawaban terhadap kebutuhan nyata masyarakat serta ditujukan untuk mengusahakan ketertiban dan kepastian. Perlu diingat bahwa kepastian hukum dari hukum positif ini masih dapat dilemahkan, baik oleh makna hukum yang kabur atau oleh perubahan hukum itu sendiri. ${ }^{19}$

Berbicara mengenai kepastian hukum, menurut O. Notohamidjodo bahwa tujuan hukum itu adalah melindungi hak dan kewajiban manusia dalam masyarakat, atas dasar keadilan untuk mencapai keseimbangan dan damai serta kesejahteraan umum, dan melindungi lembaga-lembaga sosial yang ada dalam masyarakat. ${ }^{20}$ Beliau menyatakan bahwa kehadiran hukum erat kaitannya dengan manusia dan masyarakat sehingga terjadi keselarasan antara rule dan value in social life, pendapat tersebut lebih berorientasi pada penempatan rule of law terhadap tujuannya yaitu lebih berkeadilan dan memuaskan kebutuhan sosial yang sebenarnya. ${ }^{21}$ Rule of law memiliki konsep Anglo saxon yang dalam konsep Eropa kontinental diberi nama rechtsstaat (negara hukum). Pasal 1 Ayat (3) Undang-Undang Dasar 1945 perubahan ke-4 memberikan penegasan bahwa Negara Indonesia merupakan negara hukum, dengan penegasan tersebut maka prosedur kehidupan dalam masyarakat serta negara diatur oleh hukum, baik hukum tertulis maupun hukum yang tidak tertulis, sehingga setiap masyarakat, bahkan pemerintah harus mematuhi hukum yang berlaku.

Dasar dari teori kepastian hukum dan negara hukum ialah asal legalitas yang tercantum dalam Pasal 1 Ayat (1) Kitab Undang-Undang Hukum Pidana. Pasal tersebut menyatakan bahwa tiada suatu perbuatan dapat dipidana kecuali telah diatur terlebih dahulu dalam perundang-undangan yang berlaku. Berbicara mengenai asas legalitas

17 Darji Darmodiharjo \& Shidarta, Penjabaran Nilai-nilai Pancasila Dalam Sistem Hukum Indonesia (Jakarta: Rajawali Pers, 1996). Hlm.44

18 Krisnajadi, Bab-bab Pengantar Ilmu Hukum Bagian I (Bandung: Sekolah Tinggi Hukum Bandung, 1989). Hlm.60

19 Sobandi Handy, Pembaharuan Hukum Benda Nasional Sesuai Berdasarkan Cita Hukum Pancasila (Disertasi, Universitas Parahyangan, 2011) [unpublished]. Hlm.82-83

20 Notohamidjojo, Makna Negara Hukum (Jakarta: BPK Gunung Mulia, 1970). Hlm.80-82

21 Maya Indah, Refleksi Pemikiran O.Notohamidjojo Untuk Mewujudkan Cara Berhukum Humanis (Salatiga: Balaiurang Utama UKSW, 2011). 
terdapat 3 (tiga) prinsip yang berkaitan dengan asas legalitas yaitu: pertama. Nullum crimen, nulla poena sine lege praevia prinsip ini mengandung arti bahwa tidak ada perbuatan pidana atau tidak ada pidana tanpa undang-undang yang mengaturnya. Prinsip Nullum crimen, nulla poena sine lege praevia ini memiliki konsekuensi bahwa ketentuan hukum pidana tidak berlaku surut. Kedua yaitu prinsip nullum crimen nulla poena sine lege scripta. Prinsip tersebut mengandung arti bahwa tidak ada perbuatan pidana pidana atau tidak ada pidana tanpa aturan undang-undang yang jelas. Konsekuensi dari prinsip ini ialah perbuatan yang dilarang dan diancam dengan pidana harus tertulis secara jelas dalam undang-undang. ${ }^{22}$

Ketiga, prinsip nullum crimen nulla poena sine lege certa yang mengandung arti bahwa tidak ada perbuatan pidana tanpa disertai aturan undang-undang yang jelas. Prinsip ini memiliki konsekuensi bahwa rumusan perbuatan pidana dalam undang-undang harus memiliki arti yang jelas sehingga tidak menyebabkan multitafsir dalam penerapannya. Prinsip yang ketiga nullum crimen nulla poena sine lege certa ini yang sedang diangkat oleh penulis dengan dikaitkan pada Pasal 112 dan Pasal 127 UU Narkotika. Keempat adalah prinsip nullum crimen noela poena sine lege stricta yang memiliki arti bahwa tidak akan ada perbuatan pidana tanpa ada peraturan perundang-undangan yang ketat. Prinsip ini memiliki konsekuensi bahwa penafsiran analogi tidak diperbolehkan dalam hukum pidana. Penafsiran dalam hukum pidana harus dilakukan secara ketat, hal tersebut dilakukan supaya tidak menimbulkan suatu perbuatan pidana yang baru. ${ }^{23}$

Fungsi asas legalitas sendiri menjadi perhatian Schafmeister dkk, beliau menyatakan bahwa tujuan dari asas legalitas itu sendiri ialah untuk melindungi rakyat dari pelaksanaan kekuaasaan yang tanpa batas dari pemerintah dengan menggunakan hukum pidana sebagai sarananya. Pendapat Schafmeister inilah yang dapat dikatakan bahwa undang-undang pidana memiliki fungsi sebagai perlindungan. Selain fungsi sebagai perlindungan, hukum pidana juga memiliki fungsi sebagai pelaksaaan kekuasaan pemerintah yang diizinkan dala batas-batas yang telah ditentukan oleh undang-undang. ${ }^{24}$

Fungsi asas legalitas sebagai perlindungan. Perlindungan hukum tersebut memiliki fungsi yang ditujukan untuk kepentingan pelaku. Selama perbuatan mereka bukan merupakan perbuatan yang dilarang oleh undang-undang, maka pelaku tidak dapat dituntut, sedangkan fungsi asas legalitas sebagai pembatasan ialah fungsi tersebut juga ditujukan untuk kepentingan pelaku karena para penguasa tidak dapat menuntut pelaku yang telah melakukan extra ordinary crime meskipun menimbulkan kerugian bagi korban. ${ }^{25}$ Berdasarkan asas legalitas yang telah penulis jelaskan di atas

22 Eddy OS Hiariej, Asas Legalitas dan Penemuan Hukum Dalam Hukum Pidana (Jakarta: Erlangga, 2009). Hlm.4-5

23 Ibid. Hlm.5

24 D Schaffmeister (et al), diedit oleh JE. Sahetapy, Hukum Pidana, 3 (Yogyakarta: Konsorsium Ilmu Hukum Departemen Pendidikan dan Kebudayaan RI bekerjasama dengan Liberty, 2004). Hlm.4

25 Deni Setyo Bagus Yuherawan, Dekonstruksi Asas Legalitas Hukum Pidana: Sejarah Asas Legalitas dan Gagasan Pembaharuan Filosofis Huku Pidana (Setara Press, 2014). Hlm.6 
maka Pasal 112 dan Pasal 127 UU Narkotika termasuk dalam prinsip asas legalitas yang ketiga yaitu prinsip nullum crimen nulla poena sine lege serta. Prinsip tersebut mengandung arti bahwa tidak ada perbuatan pidana tanpa disertai aturan undang-undang yang jelas. Prinsip ini memiliki konsekuensi bahwa rumusan perbuatan pidana dalam undangundang harus memiliki arti yang jelas sehingga tidak menyebabkan multitafsir dalam penerapannya.

Kepastian hukum diciptakan secara umum yaitu aturan-aturan yang mempunyai sifat umum dan berlaku umum, sehingga aturan hukum tersebut dibuat dalam bentuk peraturan-peraturan yang bisa diketahui oleh setiap orang. Kepastian hukum tidak harus bahwa untuk semua wilayah negara dalam segala hal ada satu macam aturan, bukan unifikasi dan kodifikasi hukum. penekanannya ada pada unifikasi sistem buka unifikasi peraturan. ${ }^{26}$ Bentuk peraturan bisa saja berbagai macam, tertulis maupun tidak tertulis, yang tertulis misalnya UU Narkotika sedangkan yang tidak tertulis misalnya hukum adat.

Jadi, inti dari kepastian hukum tidaklah hanya terletak pada hanya batas-batas daya berlakunya menurut wilayah atau kelompok tertentu saja, akan tetapi terletak pada: ${ }^{27}$ Kepastian mengenai bagaimana subjek hukum harus berprilaku konsisten dan harus berani menerima konsekuensinya; Kepastian mengenai bagaimana para struktur hukum harus menerapkan hukum atau mempunyai prilaku sesuai hukum. sehingga dengan kata lain dapat dikatakan kita mempunyai budaya hukum yang tinggi; Kepastian mengenai bagaimana para subjek hukum menyelesaikan permasalahan dengan hukum sebagai sarananya. Terdapat keterbukaan terhadap kritik dan berani menerima kritik yang masuk.; Kepastian mengenai bagaimana hukum tersebut berlaku pada saat peralihan. Terdapat tujuan yang jelas yaitu pada hukum yang adil serta kesejahteraan masyarakat.

Berbicara mengenai kepastian hukum dalam Pasal 112 dan Pasal 127 UU Narkotika, pasal tersebut harus memiliki suatu kaedah hukum yang tegas, jelas, tidak mempunyai arti ganda dan tidak mengakibatkan multitafsir. Pasal 112 UU Narkotika seperti yang telah dijelaskan di atas, penulis berpendapat bahwa pasal-pasal tersebut telah menimbulkan multitafsir dan ambiguitas dalam redaksinya terutama pada Pasal 112. Suatu kaedah hukum yang jelas, tegas, dan tidak mempunyai arti ganda akan membawa pada tujuan hukum itu sendiri yaitu keadilan.

Secara totalitas atau keseluruhan, kepastian hukum terdapat bukan hanya pada bentuk dan isi saja, melainkan pada kesemua sistem yang digerakkan. Dengan demikian, dibutuhkan keterbukaan dari pembuat dan pelaksana hukum, konsistensi, dan ketegasan bukan kekerasan. Dengan kata lain, kepastikan hukum tidak datang dari luar hukum melainkan datang dari dalam hukum itu sendiri ialah sistem hukum. Dari situlah bisa dikatakan bahwa kepastian hukum bukan hanya kepada orang sebagai subjek hukum atau isi hukum sebagai objek hukum, atau hanya pada proses hukum

26 Dominikus Rato, Filsafat Hukum Suatu Pengantar Mencari, Menemukan, dan Memajami Hukum, 4th ed (Surabaya: LaksBang Justitia, 2014). Hlm.79-80

27 Ibid. Hlm.166 
melainkan keseluruhan sistem hukum, baik subjek, objek, dan proses bekerjanya hukum. ${ }^{28}$

Subjek hukum yang mempunyai kesadaran mengenai hak dan kewajiban mereka, para pelaksana hukum yang sadar mengenai tugas serta wewenangnya, dan proses hukum yang dilakukan secara terbuka, konsisten, dan konsekuen. Hukum tersebut tidak berlaku secara tekstual melainkan berlaku secara kontekstual. Di katakan berlaku kontekstual artinya hukum tersebut berlaku menurut konteks waktu, konteks tempat, dan konteks personal. Hal tersebut dikatakan kepastian hukum yang konstekstual, maksudnya berlaku secara sosial dan kultural.

Hal tersebut berbanding terbalik dengan kepastian hukum yang bersifat umum. Kepastian yang bersifat umum, keadilan lebih menekankan pada faktor-faktor khusus. Keadilan ialah suatu keadaan yang serasi, selaras, dan seimbang antara hak dan kewajiban sehingga membawa ketentraman dalam kehidupan di masyarakat. Dengan kata lain, keadilan selalu mengandung penghargaan. Rasa adil dibentuk dari kecil kemudian dikontruksi dalam interaksi dengan lingkungan. Keadilan bukan hanya permasalahan individu tetapi individu dan sosial, dan tidak pula permasalahan fisik melainkan fisik maupun rohani. Dapat dikatakan bahwa, keadilan tersebut ada kalau semua orang di dalam dirinya terdapat kesadaran bahwa semua orang berhak mendapatkan penghargaan yang sewajarnya dari kelompok-kelompok tersebut atau dari kelompok yang lainnya, sedangkan kelompok tersebut tidak merasa dirugikan karena perbuatan atau kegiatan kelompok lain. ${ }^{29}$

Keadilan adalah faktor penting, tapi tidak berarti bahwa keadilan selalu bisa dengan mudah diperoleh, terlaksana atau diterapkan karena hukum juga berfungsi menjalankan ketertiban, sehingga keadilan sepatutnya diperoleh melalui perjuangan. Pandangan mengenai keadilan bisa dikorbankan demi kepastian hukum bisa terlaksana apabila kepentingan-kepentingan semua individu satu persatu diperhatikan, yang mana hal tersebut merupakan suatu hal yang mustahil.

Soerjono Soekanto menyatakan bahwa antara kepastian hukum dan keadilan adalah dua faktor yang saling menunjang satu sama lain dalam upaya menjaga keserasian atau kebandingan antara kepentingan-kepentingan yang terdapat di dalam masyarakat. ${ }^{30}$ Apabila keadilan dan kepastian hukum tersebut bisa terwujud, artinya dengan kepastian hukum tersebut keadilan dapat ditegakkan, sehingga secara dengan sendirinya hukum tersebut berfungsi. Itulah yang merupakan visi utama hukum dan tujuan utama hukum yaitu menuju pada kesejahteraan masyarakat. Kesejahteraan masyarakat bisa terwujud apabila timbul rasa tenteram, aman, tertib, serta adil. Apabila perasaan semua anggota masyarakata seperti yang disebutkan di atas tercapai, mereka akan bekerja mencari nafkah dengan lancar, kebutuhan fisik terpenuhi secara lancar tanpa hambatan untuk mencapai pada suatu kemakmuran. ${ }^{31}$

\footnotetext{
28 Logeman dalam Dominikus Rato. Ibid. Hlm.166-167

29 Selo Soemardjan dalam Dominikus Rato. Ibid. Hlm.168

30 Soerjono Soekanto dalam Dominikus Rato. Ibid.

31 Ibid. Hlml69
} 
Berdasarkan pemaparan mengenai kepastian hukum di atas, supaya kepastian hukum dalam Pasal 112 dan Pasal 127 dapat tercapai, diperlukan suatu kaedah hukum yang jelas, tegas, tidak menimbulkan arti ganda, serta tidak menimbulkan ambiguitas dalam penerapannya, selain kaedah hukum yang jelas, untuk mencapai suatu kepastian hukum juga dibutuhkan para strutktur hukum yang harus menerapkan hukum secara konsisten. Jadi, dalam Pasal 112 UU Narkotika, para struktur hukum dalam hal ini penegak hukum, harus konsisten bahwa Pasal tersebut digunakan untuk pelaku tindak pidana Narkotika saja bukan untuk penyalahguna Narkotika. Ketidak konsisten para penegak hukum dalam penerapan pasal tersebut telah mengakibatkan para pelaku tindak pidana diterapkan pasal untuk penyalahguna narkotika. Ketidak konsistenan tersebut juga akan mengakibatkan ketidak adilan bagi korban penyalahguna narkotika.

\section{KEBIJAKAN FORMULASI IUS CONSTITUENDUMTERHADAP PENYALAHGUNA DAN PELAKU TINDAK PIDANA NARKOTIKA}

Marc Ancel seperti yang dikutip oleh Barda Nawawi Arief berpendapat bahwa modern criminal science terdiri dari tiga elemen yaitu criminology, criminal law, dan penal policy. ${ }^{32}$ Menurut Marc Ancel, penal policy adalah suatu ilmu yang sekaligus seni yang pada akhirnya mempunyai tujuan praktis untuk memungkinkan peraturan hukum positif dirumuskan secara lebih baik untuk memberikan petunjuk tidak hanya kepada pembuat undang-undang, akantetapi juga kepada pengadilan yang menerapkan undang-undang dan juga kepada para penyelenggara putusan pengadilan. ${ }^{33}$ Berdasarkan penjelasan tersebut dapat digaris bawahi bahwa hakikat dari kebijakan hukum pidana bukan semata-mata menjadi tanggungjawab pekerjaan peraturan perundang-undangan yang dapat dilakukan dengan pendekatan yuridis normatif dan sistematik, selain itu kebijakan hukum pidana juga memerlukan pendekatan sosiologis, historis, dan komparatif, bahkan memerlukan pendekatan dari berbagai ilmu lain. ${ }^{34}$

Kebijakan hukum pidana dari beberapa sumber juga sering disebut juga dengan politik hukum pidana. Pengertian politik hukum pidana atau kebijakan hhukum pidana dapat kita lihat dari pengertian politik hukum maupun politik kriminal seperti yang menurut Sudarto seperti yang dikutip oleh Barda Nawawi Arief, politk hukum adalah: usaha untu mewujudkan peraturan-peraturan yang baik sesuai dengan keadaan dan situasi pada suatu saat serta kebijakan dari negara melalui badan-badan yang berwenang untuk menetapkan peraturan-peraturan yang dikehendaki yang diperkirakan dapat digunakan untuk mengekspresikan apa yang terkandung dalam masyarakat dan untuk mencapai apa yang dicita-citakan. ${ }^{35}$

32 Barda Nawawi Arief, Kebijakan Hukum Pidana, Perkembangan Penyusunan Konsep KUHP Baru (Jakarta: Kencana, Prenada Media Group, 2008). Hlm.23

33 Ibid.

34 Ibid. Hlm.24

35 Ibid. Hlm.26 
Suatu usaha untuk membuat peraturan hukum pidana yang baik pada hakikatnya tidak terlepas dari tujuan penanggulangan kejahatan. Artinya, kebijakan hukum pidana merupakan bagian dari politik kriminal, yang artinya apabila dilihat dari sudut pandnag politik kriminal maka politik hukum pidana identik dengan pengertian kebijakan penanggulangan kejahatan dengan hukum pidana. ${ }^{36}$

Kebijakan hukum pidana juga mengatur mengenai sanksi pidana. Sanksi pidana yang diterapkan harus disesuaikan dengan kebutuhan masyarakat yang dilindungi serta mempertahankan kepentingan-kepentingannya. Batas-batas sanksi pidana juga harus ditetapkan berdasarkan kepentingan dan nilai dalam masyarakat. Penggunaan sanksi pidana juga harus memberikan kesadasaran bagi pelaku kejahatan.

Kebijakan hukum pidana tidak terlepas dari tahapam kebijakan formulasi. Kebijakan formulasi yaitu seuatu tahapan penegakan hukum in abstracto yang dilakukan oleh pembuat undang-undang sehingga kebijakan ini dapat pula disebut kebijakan legislatif. Kebijakan legislatif ialah suatu perencanaan dari pembuat undang-undang mengenai apa yang akan dilakukan dalam menghadapi masalah tertentu serta bagaimana cara melaksanakan suatu yang telah direncanakan tersebut. ${ }^{37}$ Peranan legislatif meliputi suatu kebijakan dasar yang tidak hanya tentang pidananya akan tetapi juga mengenai tipe atau jenis pidana yang disediakan untuk kekuasaan pidana lainnya ditingkat yang lebih rendah serta kadar yang diberikan kepada mereka dalam menetapkan pidana yang tepat untuk seorang pelaku tindak pidana. ${ }^{38}$ A. Murder menyatakan bahwa kebijakan hukum pidana untuk menentukan: pertama, untuk menentukan seberapa jauh ketentuan-ketentuan pidana yang berlaku, perlu diubah, dan diperbaharui, kedua untuk menentukan apa yang dapat diperbuat untuk mencegah terjadinya suatu tindak pidana, ketiga untuk mementukan cara bagaimana penyidikan, penuntutan, peradilan dan pelaksanaan pidana harus dilaksanakan. ${ }^{39}$

Kebijakan formulasi terdiri dari 3 tahap penting ${ }^{40}$, yaitu pertama perumusan tindak pidana (criminal act). Tindak pidana adalah suatu oerbuatan yang pelakunya dapat dikenakan sanksi pidana atau hukuman pidana. Pelaku tersebut dapat dikatakan merupakan subjek hukum pidana, dengan demikian dalam perumusan tindak pidana harus terdapat unsur perbuatan seseorang. Unsur perbuatan seseorang tersebu pada dasarnya yang dapat melakukan tindak pidana ialah orang atau manusia alamiah. Pada perkembangannya terdapat subjek hukum baru yang dinilai dapat melakukan suatu tindak pidana dan dapat mempertanggungjawabkan perbuatannya yaitu korporasi. Unsur tindak pidana selain subjek hukum tersebut ialah perbuatan. Perbuatan yang dapat dikenai pidana sudah harus perbuatan yang memenuhi unsur delik sebagaimana

\footnotetext{
36 Ibid. Hlm.28

37 Dey Ravena \& Kristian, Kebijakan Kriminal (Criminal Policy), lst ed (Jakarta: Kencana, Prenada Media Group, 2017). Hlm.147

38 Barda Nawawi Arief, Kebijakan Legislatif Dalam Penanggulangan Kejahtan Dengan Pidana Penjara (Semarang: Universitas Diponegoro, 1994). Hlm.56

39 Barda Nawawi Arief, Beberapa Aspek Kebijakan Penegakan dan Pengembangan Hukum Pidana (Bandung: Citra Aditya Bhakti, 1993). Hlm.3

40 Ibid. Hlm.148-156
} 
yang telah dirumuskan dalam undnag-undang jadi untuk mengetahui apakah sifat perbuatan tersebut dilarang atau tidak, maka harus dilihat dari rumusan undangundangnya yang mengacu pada asas legalitas. ${ }^{41}$

Kedua perumusan pertanggungjawaban pidana. Seseorang yang telah melakukan suatu tindak pidana belum tentu dapat dipidana karena sebelum menentukan terdakwa dipidana maka yang harus dilakukan terlebih dahulu ialah apakah perbuatan tersebut merupakan tindak pidana dan apakah pelaku tersebut dapat dipertanggungjawabkan secara pidana atau tidak. Untuk menentukan suatu tindak pidana maka harus mengacu pada asas legalitas, sedangkan untuk menetukan suatu pertanggungjawaban maka harus mengacu pada kesalahan. ${ }^{42}$

Ketiga permusan sanksi baik yang berupa pidana maupun yang berupa tindakan tata tertib. Salah satu penanggulangan kejahatan dengan menggunakan hukum pidana adalah dengan penerapan sanksi pidana yang keras. Roeslan saleh dalam Dey ravena dan Kristian, menyatakan bahwa pidana adalah reaksi atas delik dan ini berujud suatu nestapa yang dengan sengaja dibebankan atau ditimpakan negara kepada pelaku tindak pidana. ${ }^{43}$ Berkaitan dengan tahap atau kebijakan formulasi, maka penjatuhan pidana memiliki arti menyangkut pembentuk undang-undang yang menetapkan stelsel sanksi hukum pidana dalam peraturan perundang-undangan yang dibuat. Penetapan tersebut harus memperhatikan aliran-aliran yang ada dalam hukum pidana serta tujuan pemidanaan, teori tujuan dan teori gabungan. Perkembangaan stelsel sanki pidana saat ini tidak hanya meliputi yang bersifat menderita tetapi juga bersifat tindakan bahkan ada beberapa undang-undang telah mengatur beberapa sanksi yang bersifat restiratif. Pengaturan sanksi pidana yang bersifat tindakan salah satunya terdapat dalam UU Narkotika Pasal 127 yang khusus dikenakan pada penyalahguna narkotika. ${ }^{44}$

Ketiga tahap kebijakan formulasi tersebut telah diterapkan dalam tindak pidana narkotikan. Pertama, perumusan tindak pidana, dalam hal ini kejahatan narkotika telah ditetapkan sebagai tindak pidana dengan diaturnya kejahatan narkotika dalam hukum positif Indonesia dengan produk hukumnya yang berupa UU Narkotika. Kedua, perumusan pertanggungjawaban pidana, dengan diaturnya kejahatan narkotika dalam hukum positif maka pertanggungjawaban pidana dapat diterapkan dan dilakukan kepada pelaku dan penyelahguna narkotika. Ketiga, perumusan sanksi pidana, dalam hal ini UU Narkotika mengatur sanksi pidana yang dapat diterapkan pada pelaku dan penyalahguna narkotika. Sanksi pidana tersebut berupa penjara, denda, dan rehabilitas bagi penyalahguna narkotika. Dengan pengaturan tersebut maka kejahatan narkotika menjadi sebuah tindak pidana yang disebut dengan tindak pidana narkotika.

Teori kebijakan formulasi tersebut digunakan untuk mengkaji dan mengevaluasi penerapan Pasal 112 dan Pasal 127 UU Narkotika. Pada penjelasan di atas telah

\footnotetext{
41 Ibid.

42 Ibid.

43 Ibid.

44 Ibid.
} 
disebutkan bahwa kedua pasal tersebut merupakan pasal yang multitafsir sehingga menimbulkan ketidakpastian hukum dalam penerapannya.

Pengaturan tindak pidana narkotika telah membuat tindak pidana narkotika memiliki suatu payung hukum dalam penerapannya. Hal tersebut tidak bertentangan dengan asas legalitas. Pada rumusan UU Narkotika saat ini terdapat beberapa pasal yang dapat dikatakan sebagai pasal multi tafsir dan menimbulkan ambiguitas dalam penerapannya. Pasal-pasal tersebut ialah Pasal 112 dan Pasal 127 UU Narkotika. Pasal 112 UU Narkotika dalam penerapannya digunakan untuk menjerat pelaku tindak pidana narkotika. Pasal 127 UU Narkotika hanya diterapkan pada penyalahguna narkotika seperti yang telah dijelaskan di atas, bahwa penggunaan pasal-pasal tersebut telah menimbulkan ketidakpastian hukum sehingga tujuan hukum itu sendiri tidak tercapai secara maksimal. Hal itu dikarenakan, banyak para pelaku tindak pidana narkotika dijerat dengan Pasal 127 UU Narkotika yang seharusnya pasal tersebut untuk para penyalahguna narkotika. Intinya bahwa masih terjadi kesalahan dalam penerapan Pasal 112 dengan Pasal 127 dalam UU Narkotika.

Hal tersebut terjadi Seperti contoh kasus Putusan Nomor: 161/Pid.Sus/ 2016/PN.Plg. Pada kasus ini terdakwa didakwa sebagai pelaku atau pengedar narkotika, akan tetapi Majelis Hakim dalam putusannya menyatakan bahwa terdakwa adalah pemakai narkotika. Kasus tersebut dengan terdakwa bernama Dedy sanjaya dan M kiki prataman. Kedua terdakwa oleh Penuntut Umum didakwa dengan dakwaan pertama Pasal 114 Ayat (1) jo Pasal 132 Ayat (1) UU Narkotika dan/atau dakwaan kedua yaitu Pasal 112 Ayat (1) UU Narkotika, dan/atau dakwaan ketiga yaitu Pasal 127 Ayat (1) Huruf a UU Narkotika jo Pasal 55 Ayat (1) ke-1 KUHP. Pada kasus ini terdakwa terbukti menguasai dan memiliki arkotika golongan 1 bukan tanaman sebanyak 1 paket sabu dengan berat 0,73 gram. Dari penemuan barang bukti tersebut seharusnya terdakwa dijerat Pasal 112 UU Narkotika. Pada kenyataannya Majelis Hakim menjatuhkan putusan dengab menyatakan bahwa terdakwa merupakan pemakai atau pecandu atau penyalahguna narkotik sehingga terdakwa di jatuhi hukuman 2 tahun penjara. Pada kenyataannya penjatuhan hukuman yang menyatakan bahwa terdakwa merupakan pemakai atau pecandu atau penyalahguna narkotika tidak diikuti atau dilakukannya tes urin kepada kedua terdakwa untuk memperjelas apakah kedua terdakwa benar sebagai pecandu atau tidak. Terdakwa dalam kasus tersebut seharusnya dikenakan Pasal 112 UU Narkotika.

Kasus di atas merupakan salah satu contoh kasus Narkotika yang disebabkan oleh Pasal 112 Ayat (1) dan Pasal 127 Ayat (1) UU Narkotika yang multitafsir dan tidak konsistennya para penegak hukum dalam menerapkan pasal. Pada kasus di atas terdakwa sejatinya didakwa dengan pasal pengedar atau pelaku tindak pidana narkotika. Pada putusannya Majelis Hakim menjatuhkan hukuman terhadap terdakwa sebagai pengguna atau pecandu atau penyalahguna narkotika. Berkaca dari kasus tersebut maka sangat diperlukan adanya suatu kebijakan formulasi yang baru terhadap pasal 112 UU Narkotika. Kebijakan formulasi tersebut bertujuan supaya para pelaku 
tindak pidana narkotika tidak bersembunyi lagi sebagai penyalahguna atau pecandu atau pemakain sehingga dapat di kenakan sanksi pidana yang semestinya.

Berdasarkan penjelasan di atas terdapat beberapa alternatif kebijakan formulasi terhadap Pasal 112 dan Pasal 127 UU Narkotika, yaitu: dengan merubah Pasal 112 dan Pasal 127 UU Narkotika. Perubahan tersebut cukup menambahi unsur-unsur pasal yang terdapat dalam Pasal 112 dengan unsur "menjual, mengedarkan". Dengan perubahan ini maka setiap pelaku tindak pidana narkotika tidak dapat bersembunyi sebagai penyalahguna narkotika. Perubahan ini perlu untuk mencegah setiap pelaku tindak pidana narkotika lolos dari jerat hukum. Dengan perubahan tersebut maka kepastian hukum dalam Pasal 112 dan Pasal 127 UU Narkotika dapat terpenuhi.

\section{PENUTUP}

Berdasarkan pembahasan di atas maka dapat disimpulkan bahwa keapstian hukum dalam Pasal 112 dan Pasal 127 UU Narkotika dapat dikatakan bahwa pasal-pasal tersbeut masih belum memberikan suatu kepastian hukum. hal tersebut dikarenakan redaksi pasal yang masih multitfasir dan mengandung arti ganda. Selain itu, para penegak hukum yang tidak konsisten dalam penerapan pasal tersebut juga menimbulkan suatu ketidakpastian hukum

Kebijakan formulasi merupakan salah satu tahap dari kebijakan hukum pidana. Kebijakan formulasi terdiri dari 3 (tiga) tahap, yaitu: pertama, perumusan tindak pidana. Kedua, perumusan pertanggungjawaban pidana. Ketiga, perumusan sanksi baik sanksi pidana maupun sanksi berupa tindakan tata tertib. Jadi, kebiajakn formulasi terhadap UU Narkotika yang dirasa cocok untuk diterapkan dimasa yang akan datang adalah merubah Pasal 112 Undang- UU Narkotika. Perubahan tersebut terjadi pada redaksi Pasal 112 dengan menambah unsur-unsur pasal yang terdapat dalam Pasal 112 UU Narkotika. Unsur pasal tersebut hanya menmbahkan kata "menjual. Mengedarkan" pada redaksinya. Dengan adanya perubaha tersebut maka setiap pelaku tindak pidana narkotika tidak dapat bersembunyi dalam Pasal 127 UU Narkotika.

Berdasarkan apa yang telah penulis paparkan di atas, maka penulis memberikan saran agar segera dilakukan perubahan terhadap UU Narkotika terutama terhadap Pasal 112. Perubahan tersebut sangat diperlukan mengingat semakin banyak nya pelaku tindak pidana narkotika yang seharusnya dijerat dengan Pasal 112 tetapi dijerat menggunakan Pasal 127.

\section{DAFTAR PUSTAKA}

- - - Kebijakan Hukum Pidana, Perkembangan Penyusunan Konsep KUHP Baru (Jakarta: Kencana, Prenada Media Group, 2008).

-_- Kebijakan Kriminal Dalam Penanggulangan Tindak Pidana Narkotika Oleh Anak, pertama ed (Malang: UMM Press, 2009). 
- - Kebijakan Legislatif Dalam Penanggulangan Kejahtan Dengan Pidana Penjara (Semarang: Universitas Diponegoro, 1994).

Adi, Kusno. Diversi Sebagai Upaya Alternatif Penanggulangan Tindak Pidana Narkotika Oleh Anak, lst ed (Malang: UMM Press, 2009).

Arief, Barda Nawawi. Beberapa Aspek Kebijakan Penegakan dan Pengembangan Hukum Pidana (Bandung: Citra Aditya Bhakti, 1993).

D Schaffmeister (et al) diedit oleh JE. Sahetapy. Hukum Pidana, 3 (Yogyakarta: Konsorsium Ilmu Hukum Departemen Pendidikan dan Kebudayaan RI bekerjasama dengan Liberty, 2004).

Darmodiharjo, Darji \& Shidarta. Penjabaran Nilai-nilai Pancasila Dalam Sistem Hukum Indonesia (Jakarta: Rajawali Pers, 1996).

Dit Narkotika Konserse Polri. Penanggulangan Penyalahgunaan dan Peredaran Gelap Narkotika yang Dilaksanakan Oleh Polri (Jakarta: Mabes Polri, 2002).

Handy, Sobandi. Pembaharuan Hukum Benda Nasional Sesuai Berdasarkan Cita Hukum Pancasila (Disertasi, Universitas Parahyangan, 2011) [unpublished].

Hiariej, Eddy OS. Asas Legalitas dan Penemuan Hukum Dalam Hukum Pidana (Jakarta: Erlangga, 2009).

Indah, CMaya. Refleksi Pemikiran O.Notohamidjojo Untuk Mewujudkan Cara Berhukum Humanis (Salatiga: Balaiurang Utama UKSW, 2011).

KEMDIKBUD. "Informasi: Temukan Bantuan Menggunakan KBBI Daring", (23 July 2018), online: kemdikbud.go.id.

Krisnajadi. Bab-bab Pengantar Ilmu Hukum Bagian I (Bandung: Sekolah Tinggi Hukum Bandung, 1989).

Marzuki, Peter Mahmud. Penelitian Hukum, revisi ed (Jakarta: Prenadamedia Group, 2015).

Notohamidjojo, O. Makna Negara Hukum (Jakarta: BPK Gunung Mulia, 1970).

Pusat Penelitian Data dan Informasi Badan Narkotika Nasional Republik Indonesia. Survei Nasional Penyalahgunaan Narkoba di 34 Provinsi Tahun 2017, Laporan Tahunan (Jakarta: Badan Narkotika Nasional Republik Indonesia, 2017).

Rato, Dominikus. Filsafat Hukum Suatu Pengantar Mencari, Menemukan, dan Memajami Hukum, 4th ed (Surabaya: LaksBang Justitia, 2014).

Ravena, Dey \& Kristian. Kebijakan Kriminal (Criminal Policy), lst ed (Jakarta: Kencana, Prenada Media Group, 2017).

Sunarso, Siswanto. Politik Hukum dalam Undang-Undang Narkotika (UU Nomor 35 Tahun 2009) (Jakarta: Rineka Cipta, 2012).

Yuherawan, Deni Setyo Bagus. Dekonstruksi Asas Legalitas Hukum Pidana: Sejarah Asas Legalitas dan Gagasan Pembaharuan Filosofis Huku Pidana (Setara Press, 2014). 